the round spermatids spermatocytes ratio was the highest on long days. But after the 24 th week, these long days were unable to maintain the testicular weight and the germ cell production, while they remained constant on short days.

Increasing the daily photoperiod from 8 to $16 \mathrm{~L}(+20 \mathrm{mn} / \mathrm{wk}$; lot 3$)$ resulted in a slightly more precocious testis growth. By contrast, the testis growth and the onset of spermatogenesis were much delayed under decreasing photoperiods ( $20 \mathrm{mn} / \mathrm{wk}$; lot 4 ). So, on the 24 th week, the testis weight was only Io gm in this lot, vs 20 gm under long photoperiods (lot I). But testis weight became very high in lot $4(22.5 \mathrm{~g})$ after 8 weeks of rapidly increasing photoperiods ( $+\mathrm{I} h / \mathrm{wk}$ ).

Applied after short days $(8 \mathrm{~L} / \mathrm{r} 6 \mathrm{D})$ when cockerels were 8 weeks old, such rapidly increasing photoperiods allowed the testes to reach adult weight as soon as the 16 th week of age.

In every lighting schedule, testis weight was decreasing as soon as adult cockerels were subjected to long photoperiods.

These observations show that the lighting schedule is an important factor in the fertility of cockerels.

\title{
EFFECTS OF FEED RESTRICTIONS APPLIED FROM HATCHING UPON TESTIGULAR DEVELOPMENT IN THE COCKEREL
}

\author{
M. de REVIERS, J. C. BLUM et B. LECLERCQ \\ Station de Recherches avicoles, \\ Centre de Recherches de Tours, I. N. R. A., \\ Nouzilly, 37380 Monnaie
}

Cockerels were either full fed ( $\operatorname{lot} \mathrm{I} ; 9^{\circ} \mathrm{o}^{\hat{0}}$ ) or restricted (lots 2 and $3 ; 9^{\circ} \delta^{\hat{t}}$ each) from hatching until they were adult ( $40 \mathrm{wks}$ ). Two types of restrictions were used; in lot 2 the cockerels were fed with I $5 \mathrm{p}$. Ioo protein, first ad libitum, then after their 5 th week, following a schedule to avoid overconsumption. In lot 3 , the cockerels were fed with a $20 \mathrm{p}$. roo protein diet during their first 5 weeks, then with the 15 p. 100 protein diet, their food intake being adjusted on that of lot 2.

Such restrictions considerably delayed the body growth until the 17 th week; then the difference between controls and restricted cockerels decreased, so that body weight became the same in every lot at the end of the experiment.

Testis growth and testicular germ cell production were similarly depressed in the two restricted lots. This could be observed as soon as the $4^{\text {th }}$ week. On the $24^{\text {th }}$ week, the mean testicular weight was only $20 \mathrm{~g}$ in lots 2 and 3 vs $30 \mathrm{~g}$ in lot $\mathrm{I}$ (controls). But when cockerels were 40 weeks old, the mean testis weight became the same in every lot (20 g), having decreased in the controls, while it remained constant in the other cockerels.

While testicular sperm production was generally higher in the controls than in the restricted cockerels, the daily sperm output, as observed by daily ejaculations, was by contrast the highest in the restricted cockerels because they were easier to handle in the BurRows and Quinn method. With respect to artificial insemination, the numbers of spermatozoa collected in restricted cockerels were enough to inseminate up to 30 hens/cockerels/day.

Such restrictions, allowing an adequate fertility in adult cockerels, ensure considerable feed savings $\left(5^{\circ} \mathrm{p}\right.$. 100 until the 17 th week). Therefore, they are of great interest for practical purposes. 